\title{
AMINOCARBONYLATION REACTION USING PALLADIUM COMPLEXES CONTAINING PHOSPHORUS- NITROGEN LIGANDS AS CATALYSTS
}

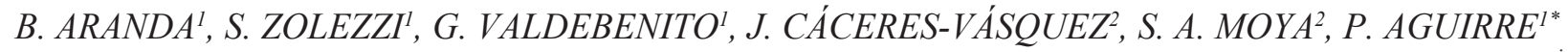 \\ ${ }^{1}$ Universidad de Chile, Facultad de Ciencias Químicas y Farmacéuticas, Casilla 233, Santiago 1, Chile. Fax 56-2- 7370567. \\ ${ }^{2}$ Universidad de Santiago de Chile, Facultad de Química y Biología, Av. Libertador Bernardo O'Higgins 3363, Casilla 40, Correo 33, Santiago, Chile.
} (Received: October 8, 2013 - Accepted: November 27, 2013)

\begin{abstract}
The catalytic activities of palladium complexes containing phosphorus-nitrogen ligands is reported. The catalysts studied showed high activities in the aminocarbonylation of aryl iodides. The palladium complexes reported activities between $100 \%$ and $58 \%$ in the aminocarbonylation reaction. The reactions are very selective for the double carbonylative amination of aryl halides. The major product is $N, N$-diethyl- $\alpha$-oxo benzeneacetamide (96/4). The reaction was made under mild conditions of temperature and carbon monoxide pressure.
\end{abstract}

\section{INTRODUCTION}

During the last few years significant advances have been achieved in the development of cross-coupling methods for the synthesis of different classes of aromatic carbonyl compounds. Transition metal-catalyzed carbonylation of aryl halides in the presence of nucleophiles is an efficient method for the preparation of such compounds [1]. Amides, as an important subgroup of carbonyl compounds, are widely used in medicinal chemistry [2].The introduction of a carboxamide moiety into a skeleton of practical importance, via simple homogeneous catalytic methods, is of high interest $[1,2,3]$.There are a number of applications for both the synthesis of simple building blocks and for the functionalization of biologically important skeletons [4,5]. Palladiumcatalyzed carbonylation reactions, including amino- and alkoxycarbonylation and carbonylative coupling reactions, are widely used in synthetic chemistry [6]. Kollar et al. [7,8] reported several studies using palladium complexes in the aminocarbonylation of aryl halides and iodopyrazine. Heterogeneous aminocarbonylations using carbene complexes have been reported with $82 \%$ conversion under mild condition $[9,10]$. Catalytic amino carbonylation using aryl halides reported two products for this reaction (see Figure 1). Usually, the major product of the aminocarbonylation reaction is $N, N$-diethylbenzamide (1), and the minor product is $N, N$-diethyl- $\alpha$-oxo benzeneacetamide (2).<smiles>Ic1ccccc1</smiles>
$\underset{\mathrm{Et}_{2} \mathrm{NH}}{\mathrm{Pd} / \mathrm{CO}}$<smiles>CCN(CC)C(=O)c1ccccc1</smiles><smiles>CCN(CC)C(=O)C(=O)c1ccccc1</smiles>

(1)
Figure 1. Aminocarbonylation reaction

The $\alpha$-ketoamides constitute key motifs in biologically active natural products [11]. They are also versatile intermediates in organic synthesis [12]. Representative methods for the construction of $\alpha$-ketoamides include amidation of $\alpha$-keto acids and $\alpha$-keto acylhalides [13], oxidation of $\alpha$-hydroxyamides and $\alpha$-aminoamides [14] and transition-metal-catalyzed double carbonylative amination of aryl halides [15]. Here we report a selective double carbonylative amination reaction of aryl iodide using a palladium complex containing phosphorus-nitrogen ligands (Figure 2 ) as catalyst. The catalytic activities gave conversions between $58-100 \%$ with high selectivity of the $N, N$-diethyl- $\alpha$-oxo benzeneacetamide.

\section{EXPERIMENTAL SECTION}

\section{Experimental/methodology}

Phosphorous-nitrogen ligands (Figure 2) and palladium complexes were synthesized using Schlenk techniques as previously reported by us [3]. These ligands were prepared from pyridine, pyrimidine and quinoline derivatives. The ligands used in this work were L1: $\mathbf{P P h}_{3}$ (as a control ligand [2]), L2: $\mathrm{Ph}_{2} \mathrm{P}-2-(\mathrm{NH}) \mathrm{PyN}-\mathrm{PPh}_{2}$ (PyN: pyrimidine), L3: 2-(NH)Py- $\mathrm{PPh}_{2}$ (Py: pyridine),
L4: 2-( $\left.\mathrm{CH}_{3} \mathrm{NH}\right) \mathrm{Py}_{-}-\mathrm{PPh}_{2}$, L5: 2-( $\left.\mathrm{CH}_{2}\right) \mathrm{Py}-\mathrm{PPh}_{2}$, and L6: 8- $\left(\mathrm{PPh}_{2}\right) \mathrm{Qn}-\mathrm{PPh}_{2}(\mathrm{Qn}$ : quinoline).

\section{Catalytic reaction}

Iodobenzene aminocarbonylation was carried out in a high-pressure, temperature-controlled reactor. This reaction can be carried out using a palladium(II) complex containing P-N ligands, or a palladium(II) precursor $\left(\mathrm{Pd}(\mathrm{OAc})_{2}\right)$ and the ligand added "in situ". Aryl iodide substrate, amine (diethylamine), solvent (DMF), and catalyst were mixed in a Schlenk tube under a nitrogen atmosphere, and then loaded in a previously vacuumed reactor. Carbon monoxide (30 bar) was charged separately and the reactor was set up at $90{ }^{\circ} \mathrm{C}$. Samples were collected every 1 hour and analyzed in a HP 5890 Series II Gas Chromatograph equipped with a FID. GC-mass spectroscopy was used in order to confirm the product of the reaction.

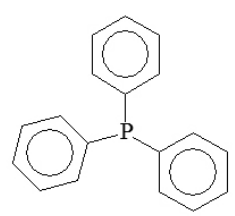

L1

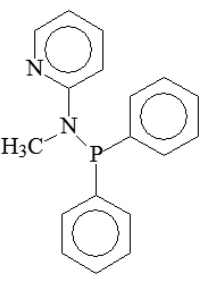

L4

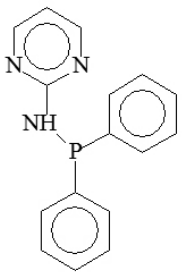

L2

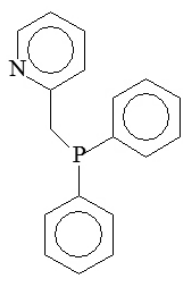

L5

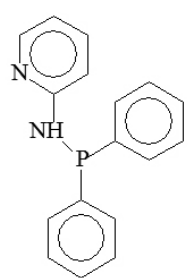

L3

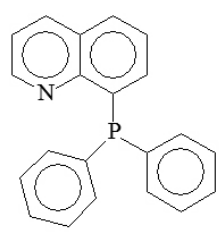

L6
Figure 2: Phosphorus - Nitrogen ligands.

\section{RESULTS AND DISCUSSION}

Table 1 shows the catalytic results of the aminocarbonylation of aryl iodide carried out with palladium(II) systems using several phosphorusnitrogen derivatives. The catalytic reaction reported activities between $58 \%$ $100 \%$, with a major selectivity towards the double carbonylation of aryl iodide ( $N, N$-diethyl- $\alpha$-oxo benzeneacetamide). The activities were compared with the classic system using palladium(II) and triphenylphosphine ligands (entry 1). When palladium(II)/phosphorus-nitrogen ligand systems were used, it was possible to observe that the selectivity depends on the phosphorus- 
nitrogen ligands properties and that selectivity was greater than with the $\mathrm{Pd}(\mathrm{II}) /$ triphenylphosphine system. These systems were studied using in situ palladium(II) (1 equiv.) and $\mathrm{P}-\mathrm{N}$ ligands $\mathrm{L}_{2}=\mathrm{Ph}_{2} \mathrm{P}-2-(\mathrm{NH}) \mathrm{PyN}_{-} \mathrm{PPh}_{2}(2$ equiv.), reporting high conversion and moderate selectivity of the double carbonylation of aryl iodide; on the other hand, in situ $\mathrm{Pd}(\mathrm{II})$ (1 equiv.) systems with ligand $\mathrm{L}_{3}=2$-(NH)Py- $\mathrm{PPh}_{2}(2$ equiv.) reported an activity of $97 \%$ with high selectivity towards the aketoamide product. When we compare the basicity of ligands $\mathrm{L}_{2}$ and $\mathrm{L}_{3}$ (entries 2,3), problably the lower basicity of the $\mathrm{L}_{3}$ ligand favors the selectivity of the reaction to the double carbonylation of aryl iodide; however, in both experiments (entries 2 and 3 ) the conversions were near $100 \%$. When the catalytic reaction was carried out using a pre-catalyst previously synthesized from $\mathrm{Pd}(\mathrm{II})$ acetate with a $\mathrm{PN}$-type ligand such as $\mathrm{L}_{3}$, the activity achieved by the resulting $\mathrm{Pd}\left(2-(\mathrm{NH}) \mathrm{Py}-\mathrm{PPh}_{2}\right)_{2}(\mathrm{OAc})_{2}$ complex was only $74 \%$, but the selectivity was $94 \%$ for the double carbonylation of aryl iodide Normally the pre-formed catalyst complex increases the control on the selectivity of the reaction, so perhaps when the reaction was made using an in situ $\mathrm{Pd}(\mathrm{II}) / \mathrm{L}_{3=}$ 2-(NH)Py- $\mathrm{PPh}_{2}$ system, the reaction promotes the formation of other palladium complexes that are not selective for the double carbonylation. A similar behavior was seen when the $\mathrm{Pd}\left(2-\left(\mathrm{CH}_{2}\right) \mathrm{Py}-\mathrm{PPh}_{2}\right)_{2}(\mathrm{OAc})_{2}$ and $\mathrm{Pd}\left(8-\left(\mathrm{PPh}_{2}\right) \mathrm{Qn}-\mathrm{PPh}_{2}\right)_{2}(\mathrm{OAc})_{2}$ complexes were studied. The $\mathrm{Pd}\left(2-\left(\mathrm{CH}_{2}\right) \mathrm{Py}-\right.$ $\left.\mathrm{PPh}_{2}\right)_{2}(\mathrm{OAc})_{2}$ complex (entry 6 ) reported $99 \%$ conversion with $89 \%$ selectivity for the $\alpha$-ketoamides after only 4 hours of reaction, while the $\mathrm{Pd}\left(8-\left(\mathrm{PPh}_{2}\right) \mathrm{Qn}\right.$ $\left.\mathrm{PPh}_{2}\right)_{2}(\mathrm{OAc})_{2}$ complex (entry 7) reported lower conversion (58\%) but high selectivity $(96 \%)$ for the $N, N$-diethyl- $\alpha$-oxo benzeneacetamide. When $\mathrm{Pd}(\mathrm{OAc})_{2}$ was studied as test reaction, the palladium compound decompose rapidly to palladium metal. In the presence of phosphorus-nitrogen ligands the generation of palladium metal is avoided. We found a series of palladium complexes containing phosphorus-nitrogen ligands with high activity and selectivity for the catalytic synthesis of $N, N$-diethyl- $\alpha$-oxo benzeneacetamide. The product of the catalytic reaction is easy to purify by column chromatography using basic alumina in dichloromethane. Comparing the results reported here with those reported in the literature it is possible to point that our systems require only 4 hours of reaction to achieve high activities and selectivities. Other studies using palladium catalysts $[16,17]$ and copper catalysts $[18-20]$ have shown longer reaction time for the aminocarbonylation (over 10 hours), with lower selectivity compared to those reported here. On the other hand, the amount of catalyst required for the aminocarbonylation of the aryl iodide reaction in our study is less than that reported in the literature [7], giving higher yields.

Table 1: Catalytic activities of palladium compounds in aminocarbonylation of Aryl iodide.

\begin{tabular}{|c|c|c|c|}
\hline \multirow{2}{*}{ Entry } & $\begin{array}{c}\text { Pd(II)/Ligand or } \\
\text { palladium complex }\end{array}$ & $\begin{array}{c}\text { Conversion } \\
\%\end{array}$ & $\begin{array}{c}\text { Selectivity } \\
\%\end{array}$ \\
\cline { 3 - 4 } & & & ratio 2/1 \\
\hline 1 & $\mathrm{Pd} / \mathrm{PPh}_{3}$ & 96 & $71 / 29$ \\
\hline 2 & $\mathrm{Pd} / \mathrm{L}_{2}$ & 100 & $60 / 40$ \\
\hline 3 & $\mathrm{Pd} / \mathrm{L}_{3}$ & 97 & $90 / 10$ \\
\hline 4 & $\mathrm{Pd}\left(2-(\mathrm{NH}) \mathrm{Py}-\mathrm{PPh}_{2}\right)_{2}(\mathrm{OAc})_{2}$ & 74 & $94 / 6$ \\
\hline 5 & $\mathrm{Pd}\left(2-\left(\mathrm{CH}_{3} \mathrm{NH}\right) \mathrm{Py}-\mathrm{PPh}_{2}\right)_{2}(\mathrm{OAc})_{2}$ & 99 & $71 / 29$ \\
\hline 6 & $\mathrm{Pd}\left(2-(\mathrm{CH}) \mathrm{Py}-\mathrm{PPh}_{2}\right)_{2}(\mathrm{OAc})_{2}$ & 99 & $89 / 11$ \\
\hline 7 & $\mathrm{Pd}\left(8-\left(\mathrm{PPh}_{2}\right) \mathrm{Qn}-\mathrm{PPh}_{2}\right)_{2}(\mathrm{OAc})_{2}$ & 58 & $96 / 4$ \\
\hline
\end{tabular}

Conditions: substrate/catalyst ratio 100:1, $1.5 \mathrm{~mL} \mathrm{Et}_{3} \mathrm{~N}, 10 \mathrm{~mL}$ DMF, 30 bar $\mathrm{CO}$

$\mathrm{T}=90^{\circ} \mathrm{C}$. Reaction time $=4$ hours. ${ }^{\text {a }}$ ratio of the products $(2) /(1) . \mathrm{Pd}(\mathrm{OAc})_{2}$ used as test reaction yield $10 \%$ conversion with inverse selectivity $(1) /(2)=$ $92 / 8$.

\section{CONCLUSIONS}

We developed a series of transition-metal-catalyzed systems using homogenous palladium complexes containing phosphorus-nitrogen ligands that are very active in the aminocarbonylation of aryl iodide reaction. The synthesized complexes showed conversions between 58\%-100\%. Several complexes studied in this work reported high selectivity for the ketocarboxyl amine after only 4 hours of reaction.

\section{ACKNOWLEDGEMENTS}

We wish to express our thanks for the financial support provided by Fondecyt-Chile (Grant 1120149)

\section{REFERENCES}

1. E. Szanti-Pinter, J. Balogh, Z. Csok, L. Kollár, A. Gomory, R. SkodaFoldes. Steroids, 2001, 76, 1377.

2. Z. Trzeciak. Coord. Chem. Rev. 2005, 249, 2308.

3. P. Aguirre, C. Lagos, S.A Moya, C. Zúñiga, C. Vera-Oyarce, E. Sola, G. Peris, J.C Bayón. Dalton Trans. 2007, 46, 5419.

4. X-F. Wu, J. Schranck, H. Neumann, M. Beller. Tetrahedron Letters 2011, 52, 3702.

5. P.J. Tambade, Y.P. Patil, B.M. Bhanage. Appl. Organometal. Chem. 2009, 23, 235.

6. (a) B. Malawskai, K. Kulig, J. Gajda, D. Szczeblewki, A. Musaial, K. Wickowski, D. Maciag, J.P. Stables. Acta Pol. Pharm. Drug Res. 2007, 64, 127; (b) B. Malawska. Curr. Top. Med. Chem. 2005, 5, 69; (c) J.J. Luszczki, M.J. Swiader, K. Swiader, R. Paruszewski, W.A. Turski, S. Czuczwar. J. Fund. Clin. Pharmacol. 2008, 22, 69.

7. R. Skoda-Foldes, L. Kollar. Curr. Org. Chem. 2002, 6, 1097.

8. A. Arcadi. Carbonylation of Enolizable Ketones (Enol Triflates) and Iodoalkenes (Chapter 9) In Modern Carbonylation Methods; Kollar, L., Ed.; Wiley-VCH: Weinheim, 2008, 223.

9. Applied Homogeneous Catalysis with Organometallic Compounds; B. Cornils, W. A. Herrmann. Eds.; Wiley-VCH: Weinheim, 1996.

10. Transition Metals for Organic Synthesis; M. Beller, C. Bolm. Eds.; Wiley-VCH:Weinheim, 1998.

11. S. Álvarez, R. Álvarez, H. Khanwalkar, P. Germain, G. Lemaire, F. Rodríguez-Barrios, H. Gronemeyer and Á. R. de Lera. Bioorg. Med. Chem. 2009, 17, 4345.

12. J. L. Jesuraj and J. Sivaguru. Chem. Commun. 2010, 4791.

13. F. Heaney, J. Fenlon, P. McArdle and D. Cunningham. Org. Biomol. Chem. 2003, 1, 1122.

14. T. D. Ocain and D. H. Rich. J. Med. Chem.1992, 35, 451.

15. F. Ozawa, H. Soyama, H. Yanagihara, I. Aoyama, H. Takino, K. Izawa, T. Yamamoto and A. Yamamoto. J. Am. Chem. Soc., 1985, 107, 3235

16. Z. Tao, C. Zhen-Chu. J. Chem. Research (S), 2001, 116.

17. J. Liu, S. Zheng, W. SUN, C. Xia Chin. J.of Chem., 2009, 27, 623.

18. J. Liu, R. Zhang, S. Wang, W. Sun, and C. Xia. Org. Lett., 2009, 11, 6.

19. M. Wen-Peng, W. Hui-Hui, L. Zhi-Cheng, Y. Jin-Wei, X. Yong-Mei,Y. Liang-Ru M. Pu and Q. Ling-Bo. Chem. Commun., 2012, 48, 10117.

20. J. Zhang, Y.Wei, S. Lin, F. Liang and P.Liu. Org. Biomol. Chem., 2012, 10,9237 . 